\title{
The Relationship Between Perceptions of Social Support and Self-Esteem in University Graduates
}

\author{
Wellyda Olga Hutagalung ${ }^{1}$ Denrich Suryadi ${ }^{1 *}$ \\ ${ }^{I}$ Faculty of Psychology, Universitas Tarumanagara, Jakarta, Indonesia \\ *Corresponding author. Email: denrichs@fpsi.untar.ac.id
}

\begin{abstract}
University graduates in most countries are facing difficulty in finding work along with the complexity of job integration. University graduates during their study learn strictly basic concepts without further application and this leads to them not being ready for work. This has resulted in university graduate unemployment rates being consistently higher than the adult population of many countries. The intense competition in the job market requires university graduates to have good self-esteem in order to be more confident in developing their career. Strengthening the career adaptability of a university graduate requires more than just improving self-esteem. It involves social support from the people in their life. This study aims to determine the relationship between perceptions of social support and self-esteem in university graduates.
\end{abstract}

\section{Keywords: perceptions of social support, self-esteem, university graduate}

\section{INTRODUCTION}

The unemployment rate among university graduates is consistently higher than that of the adult population in many countries, and this has become a new social problem [1]. When viewed from the perspective of university graduates themselves, it is found that while studying in university they learn only basic concepts without further application and this causes them to not be ready for work [2]. This is apart from the problem of mismatch between the skills possessed and the demands of the expected level of work because university graduates tend to lack work experience.

Based on data from the 2018 Higher Education Statistics Book of the Ministry of Research, Technology and Higher Education, the number of tertiary education graduates in Indonesia in 2018 was 1.2 million. Individuals who have just graduated tend to try to get a job or develop a career. Research [3] found that unemployed individuals had, on average, about one point lower on life satisfaction scale compared to individuals who had steady jobs. The presence of family and social pressures associated with job search activities and higher expectations on university graduates also serve as potential mediators of stress and depression among university graduates [4]. On the other hand, there was a significant reduction in stress levels for university graduates who got their desired jobs, demonstrating how important work is to them. It seems clear that both unemployment and underemployment status are a cause of stress for university graduates, while finding a job that fits their career plan has significant mental health benefits [5].

Self-esteem plays an important role as the key to maintaining a positive attitude towards life and being able to influence the cognition of every human being [6]. It is important for university graduates to develop better selfesteem in order to be more confident in preparing themselves to develop a career according to [7]. This attitude can bring individuals to success, trigger selfconfidence, and improve self-esteem [8].

Rosenberg's theory measures self-esteem globally in adolescence and early adulthood. Furthermore, [9] selfesteem is directly and indirectly related to adaptation with the support from family, friends, and important people during an individual's life. In strengthening the career adaptability, a university graduate requires more than just a focus on increasing self-esteem. It needs to involve social support from people in their life [10].

[11] stated that the perception of social support is the assistance received by individuals which comes from family, friends, and significant others. There are two dimensions of social support, namely; perceived social support and received social support. Perceived social support is seen as an individual's perception of the amount and quality of support received from his/her social network, whereas received social support is defined as calculating the purpose of assistance and assistance received by individuals from his/her social network [10]. Self-esteem is hypothesized to be an important mediator because individuals with very low social support are rarely satisfied with themselves and are more likely to possess low self-esteem, which would significantly worsen their psychological well-being [11]. A consequence model of self-esteem suggests that individuals with a positive level of perceived social support show higher self-esteem, or a higher sense of social value [12]. 


\section{THEORETICAL REVIEW}

According to Rosenberg (1965), self-esteem is defined as an attitude, liked or disliked, of an individual. There are two types of approaches in understanding self-esteem, namely, global self-esteem and specific self-esteem [13]. Global self-esteem is manifested in feelings about oneself, whereas certain aspects of self-esteem include various thoughts related to oneself, while specific self-esteem assesses oneself from various aspects.

[13] stated that the perception of social support is the assistance received by individuals which comes from family, friends, and significant others. Perception of social support according to (Barrera, 1986) in [14] is a cognitive assessment of individuals who are able to connect well with other people. Perceptions of social support plays an important role for individuals to be able to adapt to new situations and environments and to gain self-confidence [15].

It is an accepted fact by most people that the family is the most important source of the perception of social support for an individual as a social being [16]. Individuals with high self-esteem show more ways of coping with problems and challenges in life than individuals who do not [17]. High self-esteem has been shown to be associated with better outcomes in several aspects such as mental health, better coping skills, and is also associated with a lower risk of depression in both adolescents and adults [18].

\section{RESEARCH METHOD}

Participants in this study were university graduates who according to [20] are individuals who had legally graduated from university within a minimum period of six months. Meanwhile, the definition of a university graduate is an individual who has just completed a higher education level, as those who have a bachelor's degree or undergraduate (S1) and do not have formal work experience within a maximum time limit of up to 1 year [20]. Data collection was done using questionnaire and research sampling uses non-probability sampling technique. This research is a non-experimental, quantitative correlational research.

In this study, the total number of participants involved was 120 people. The distribution of research participants was divided into gender, age, and the faculty origin of the participants. An overview of the distribution of participants can be seen in the following tables:

Table 1 Description of the Distribution of Participant Data by Gender

\begin{tabular}{cccc}
\hline Gender & Frequency & Percentage & Cumulative \\
& & & \\
\hline Male & 39 & 32,5 & 32,5 \\
Female & 81 & 67,5 & 100,0 \\
& & & \\
Total & 120 & 100,0 & 100,0 \\
\hline
\end{tabular}

The first dissemination of participant data based on gender. Based on the table above, it can be seen that the number of male research participants was 39, with a percentage of $32.5 \%$ of the total study participants. Furthermore, the number of female research participants amounted to 81 people, with a percentage of $67.5 \%$ of the total study participants. The distribution of data on participants in the second study was based on age.

Table 2 Description of the Distribution of Research Participants by Age

Age Frequency Percentage Cumulative

\begin{tabular}{cccc}
\hline 20 & 10 & 8,3 & 8,3 \\
21 & 27 & 22,5 & 30,8 \\
22 & 41 & 34,2 & 65,0 \\
23 & 23 & 19,2 & 84,2 \\
24 & 10 & 8,3 & 92,5 \\
25 & 9 & 7,5 & 100,0 \\
& & & \\
Total & 120 & 100,0 & 100,0 \\
\hline
\end{tabular}

Based on the data from the table above, it can be seen that the participants of this study were included in the category of young adults. The age interval that dominates the participants of this study is the age of 22 years with a total of 41 people and a percentage of $34.2 \%$ of the total study participants. Then, followed by the 21 year age group with a total of 27 people and a percentage of $22.5 \%$ of the total study participants. Then, the next age interval is 23 years with the number of study participants as many as 23 people and a percentage of $19.2 \%$ of the total study participants.

Other age categories did not have a significant difference in numbers, except at the age of 20 and 24 which had the same number, namely $8.3 \%$ of participants.

Table 3 An overview of the distribution of participants based on the origin of the faculty

\begin{tabular}{lcc}
\hline \multicolumn{1}{c}{ Faculty } & Frequency & Percentage \\
\hline Economy & 12 & 10,0 \\
Psychology & 35 & 29,2 \\
Law & 11 & 9,2 \\
Technique & 13 & 10,8 \\
Medical & 6 & 5,0 \\
Information & 7 & 5,8 \\
Technology & & \\
Fine Art Design & 7 & 5,8 \\
Communication & 4 & 3,3 \\
Others & 25 & 20,8 \\
\multicolumn{1}{c}{ Total } & & \\
\hline
\end{tabular}

The table above shows an overview of the distribution of research participants based on the faculty origin of the participants. Based on the origin of the faculty, the group 
of participants is divided into nine categories, namely, the faculties of economics, psychology, law, engineering, medicine, information technology, art and design, communication, and others. The largest number of participants from the faculty origin category came from the Psychology faculty with a total of 35 participants with a percentage of $29.2 \%$. The second largest number came from other faculties, namely 25 people with a percentage of $20.8 \%$ of the total research participants. As long as the other faculties do not have a significant difference.

\section{DATA ANALYSIS}

In this study, the total number of participants was 120 people consisting of 39 men and 81 women. The research hypothesis states that there is a positive relationship between perceptions of social support and self-esteem. The data processing used SPSS v.25 application, using Spearman correlation test. For $\mathrm{N}=120$ and a significance level of $(\alpha=5 \%)$, the result is $r=0.041$, which indicates that the perception of social support and self-esteem is significantly related. This shows that there is a relationship between the perception of social support and self-esteem in university graduates.

The researchers found that there is a positive correlation between perceptions of social support and the self-esteem of university graduates. A positive correlation indicates that if the value of one variable increases, the value of the other variable will also increase. For this reason, it can be predicted that the higher the perception of social support an individual has, especially university graduates, the higher the self-esteem.

Table 4 Correlation between Perceptions of Social Support and Self-Esteem

\begin{tabular}{cc}
\hline Variable & Sig \\
\hline $\begin{array}{c}\text { Perceptions of Social } \\
\text { Support }\end{array}$ & 0,041 \\
\hline
\end{tabular}

\section{CONCLUSION}

In this study, the total number of participants involved was 120 people consisting of 39 men and 81 women. The research hypothesis states that there is a positive relationship between the variable perceptions of social support and self-esteem. From the results of research data processing using the SPSS 25 application, with data analysis techniques Spearman correlation test. This means that for $\mathrm{N}=120$ and a significance level of $(\alpha=5 \%)$, the result is $\mathrm{r}=0.041$ which indicates that the perception of social support and self-esteem is significantly related to 1.o.s 0.05. This significant relationship makes the null hypothesis rejected and the alternative hypothesis accepted, so it can be interpreted that there is a positive relationship between the perception of social support and self-esteem in university graduates.
Researchers found that there was a positive correlation between perceptions of social support and the self-esteem of university graduates. A positive correlation indicates that the value of one variable increases, so the value of the other variable will also increase. For this reason, it can be predicted that the higher the perception of social support an individual has, especially university graduates, the higher the self-esteem of that individual. Based on the analysis conducted, it can be concluded that there is a significant positive relationship between the perception of social support and self-esteem in university graduates. That is, the higher the perception of social support, the higher the self-esteem among university graduates.

\section{DISCUSSION}

The authors discovered a phenomenon happening in most countries that university graduates experience a financial crisis and feel unable to be integrated in society. The findings of [21] imply that individuals with high selfesteem fight for their lives persistently and are able to face all potential threats. A consequence model of self-esteem suggests that positive social support can result in higher self-esteem [22]. In particular, higher self-esteem can lead individuals to develop positive social support networks because of their belief in their social value. Whereas individuals with lower self-esteem have difficulty building positive social support systems because they usually avoid social interactions due to fear of rejection by others [22]. Then based on the results of the analysis in the additional data analysis table, it was found that the three dimensions of the variable social support perception showed a significance to the self-esteem of university graduates. With the increasing need for knowledge in workers, the demand for competent new university graduates is the key to human capital that has grown substantially [23]. High self-esteem is associated with feelings of certainty and resilience to stressful or uncertain states [24]. Individuals with high self-esteem have relatively more self-confidence [25]. Based on the results of the analysis of research data and the results of the discussion above, it can be concluded that good self-esteem comes from the perception of social support that an individual has, especially among university graduates, is important.

There are two factors according to [18] that influence a person's self-esteem, first internal factors such as intrinsic factors which are characterized by qualities that early adulthood may have inherently, such as social competence or positive identity. Extrinsic factors are those characterized by environmental aspects of young adult life such as the support, boundaries and expectations of families and educational institutions. This is confirmed through the results of the score interval category on the three dimensions of perceptions of social support, namely friends, family, and significant others, which shows that in the category of significant others dimensions, university graduates who are in the high category are $83.3 \%$. There are $85.8 \%$ of the family dimension category of university graduates who are in the high category, and the dimension 
category of friends of university graduates who are classified as high category is $73.3 \%$. [18] also estimate the contribution of individual developmental factors, both internal and external, which is associated with the maintenance of high self-esteem in early adulthood.

Based on the results of the research and discussion above, it can be said that the perception of social support which consists of three dimensions, namely family, friends, and significant others has a positive correlation to one's selfesteem, especially in this study are university graduates. The perception that the individual has about how much support he feels from his immediate or social environment is able to influence the assessment of his self-esteem, so that the higher the perception of social support obtained by university graduates, the more high self-esteem too.

\section{SUGGESTION}

Based on the research results that have been obtained, the authors suggest several things related to theoretical benefits and also for further research. The first suggestion, if research participants continue to use university graduates, the next researcher can consider as well as pay attention to the distribution of the number of participants by gender. This is intended so that the results of the research that will be obtained can be more even and balanced in terms of the gender of the participants and the implications of this evenly distributed data can make the results of the research data more representative. The second suggestion departs from the research background that it is known that workers' skills are considered as a key variable capable of influencing the competitiveness of a company, so the researcher suggests considering the addition of worker skills variables in future studies. The third suggestion, in the data collection method, it would be even better if the next researcher used interview techniques to prospective research participants. This is useful for obtaining accuracy between the point of view of the researcher and the situation directly experienced by potential participants through in-depth interviews with several individuals.

After providing some suggestions related to theoretical benefits, the author will also provide suggestions related to the practical benefits of this research. For research participants, that is, university graduates to be able to complete their abilities through several ways such as taking special training related to their respective fields with the aim of accelerating the adaptation process in the work environment as well as being able to increase selfconfidence as university graduates the workplace. The next thing that can be done by the social environment consisting of family, friends, and other important people is by providing affective support needed by university graduates, through good quality social interactions, so that the need for affection support can be met properly. Then, the next practical advice that can help university graduates to increase their self-esteem can be through the fulfillment of informational support by continuing the master study program or taking a professional program. This is in accordance with the definition of informational support, namely, the support that individuals get when interacting with people who advise, provide advice, and support to guide individuals.

Further practical advice, graduates should increase their confidence in their abilities through means such as conducting self-evaluation by knowing their weaknesses and strengths as well as measuring their own abilities during the waiting period. After knowing this, the author suggests comparing the skills mastered with the demand for the labor market. Taking several internship opportunities will help increase skills, knowledge, selfconfidence and even add to the portfolio in the CV.

Finally, for university graduates, it is advisable to show new skills by updating the profile information on professional social media accounts and adding data to CVs and resumes. Practicing short speeches for a job interview can also boost your confidence. Good self-confidence will open wider opportunities for job success for university graduates in starting their careers.

Furthermore, suggestions for companies or employing organizations would be able to adjust the expectations of their employees who are still included in the category of new university graduates as well as provide opportunities for them to demonstrate their abilities and performance. Adjusting these expectations is suggested through persuasive ways such as providing motivation and social support from the workplace for employees who are new university graduates with the hope of being able to increase self-confidence and confidence in work performance.

\section{REFERENCES}

[1] Yunikawati, N. A., Prayitno, P. H., Purboyo, M. P., Istiqomah, N., \& Yunika, E. (2018). Causes and Solution To Reduce Unemployment Vocational School Graduate in Indonesia. UNEJ E-Proceeding, November 2017, 200-207.

[2] Suryani, A. W. (2018). The Supply Shortage of Accounting Graduates in Indonesia: The Public Accounting Firms Perspective. KnE Social Sciences, 3(3), 374. https://doi.org/10.18502/kss.v3i3.1896

[3] Voßemer, J., Gebel, M., Täht, K., Unt, M., Högberg, B., \& Strandh, M. (2018). The Effects of Unemployment and Insecure Jobs on Well-Being and Health: The Moderating Role of Labor Market Policies. Social Indicators Research, 138(3), 1229-1257. https:// doi.org/10.1007/s11205-017-1697-y

[4] Rafi, M. A., Mamun, M. A., Hsan, K., Hossain, M., \& Gozal, D. (2019). Psychological Implications of Unemployment Among Bangladesh Civil Service Job Seekers: A Pilot Study. Frontiers in Psychiatry, 10. https://doi.org/10.3389/fpsyt.2019.00578 
[5] Cassidy, T., \& Wright, L. (2008). Graduate employment status and health: A longitudinal analysis of the transition from student. Social Psychology of Education, 11(2), 181-191. https://doi.org/10.1007/ s11218-007-9043-x

[6] T. Aruna Bharathi, T. A. B. (2017). A Study on the Self-Esteem Level among the Students of University of Home Science. International Journal of Educational Science and Research, 7(5), 71-76. https://doi.org/10. 24247/ijesroct201711

[7] Mahadi, H., Abdullah, N., Ph'ng, L. M., Hasan, H., \& Ariffin, H. (2016). Self-esteem, social support and career decision-making among technical engineering students. Social Sciences (Pakistan), 11(12), 29712976. https://doi.org/10.3923/sscience.2016.2971.2976

[8] Abbassi, R., \& Sta, N. (2019). The Effect of selfesteem, entrepreneurship education, and entrepreneurial tradition of the family on the entrepreneurial intention among students. Journal of Business and Management Research, 12, 235-245. http://www.knowledgejournals. com/PDF/191.pdf

[9] Hui, T., Yuen, M., \& Chen, G. (2018). Career Adaptability, Self-Esteem, and Social Support Among Hong Kong University Students. Career Development Quarterly, 66(2), 94-106. https://doi.org/10.1002/cdq. 12118

[10] Zimet, G. D., Dahlem, N. W., Zimet, S. G., Gordon, K., \& Farley, G. K. (2010). The Multidimensional Scale of Perceived Social Support The Multidimensional Scale of Perceived Social Support. Journal of Personality Assessment, 52(1), 3741. https://doi.org/10.1207/s15327752jpa5201

[11] Mahon, N. E. (2001). Social Support and WellBeing in Early Adolescents. 10(2), 163-181.

[12] Marshall, S. L., Parker, P. D., Ciarrochi, J., \& Heaven, P. C. L. (2014). Is Self-Esteem a Cause or Consequence of Social Support? A 4-Year Longitudinal Study. Child Development, 85(3), 1275-1291. https:// doi.org/10.1111/cdev.12176

[13] Baumeister, R., Campbell, J., Krueger, J., \& Vohs, K. (2003). Does high self-esteem cause better performance, interpersonal success, .... Psychological Science in the Public Interest, 4(1), 1-44.

[14] Li, B., Pan, Y., Liu, G., Chen, W., Lu, J., \& Li, X. (2020). Perceived social support and self-esteem mediate the relationship between childhood maltreatment and psychosocial flourishing in Chinese undergraduate students. Children and Youth Services
Review, 117(July). https://doi.org/10.1016/j.childyouth. 2020.105303

[15] Polatci, S. (2015). ÖRGÜTSEL VE SOSYAL DESTEK ALGILARININ YASAM TATMINI ÜZERINDEKI ETKISI : IŞ VE EVLILIK TATMINININ ARACILIK ROLÜ THE EFFECTS OF PERCEIVED ORGANIZATIONAL AND SOCIAL SUPPORT ON LIFE SATISFACTION: THE MEDIATION ROLE OF JOB AND MARRIAGE. 11(2), 25-44.

[16] Işik, E. (2016). Mesleki Sonuç Beklentisinin Yordaylcllarl Olarak Algllanan Sosyal Destek ve Denetim Oda $\breve{g}_{l}$ *. November. https://doi.org/10.12738/ estp.2013.3.1520

[17] Orth, U., \& Robins, R. W. (2014). The Development of Self-Esteem. Current Directions in Psychological Science, 23(5), 381-387. https://doi.org/ $10.1177 / 0963721414547414$

[18] Birndorf, S., Ryan, S., Auinger, P., \& Aten, M. (2005). High self-esteem among adolescents: Longitudinal trends, sex differences, and protective factors. Journal of Adolescent Health, 37(3), 194-201. https://doi.org/10.1016/j.jadohealth.2004.08.012

[19] Nor Afiqah Wan Othman, W., Abdullah, A., \& Romli, A. (2020). Predicting Graduate Employability based on Program Learning Outcomes. IOP Conference Series: Materials Science and Engineering, 769(1). https://doi.org/10.1088/1757-899X/769/1/012018

[20] Jusoh, M., Razak, M. R. A., \& Chong, S. C. (2007). Employers' preference and assessment of the qualities of fresh business graduates: Empirical evidence from Malaysia. International Journal of Management and Enterprise Development, 4(3), 316336. https://doi.org/10.1504/IJMED.2007.012682

[21] Kernis, M. H. (2005). Measuring self-esteem in context: The importance of stability of self-esteem in psychological functioning. Journal of Personality, 73(6), 1569-1605. https://doi.org/10.1111/j.1467-6494. 2005.00359.x

[22] Feng, D., Su, S., Wang, L., \& Liu, F. (2018). The protective role of self-esteem, perceived social support and job satisfaction against psychological distress among Chinese nurses. Journal of Nursing Management, 26(4), 366-372. https://doi.org/10.1111/ jonm. 12523

[23] Promís, P. (2008). Are employers asking for the right competencies? A case for emotional intelligence. Library Administration and Management, 22(1), 24-30. 
[24] Stinson, D. A., Logel, C., Zanna, M. P., Holmes, J. G., Cameron, J. J., Wood, J. V., \& Spencer, S. J. (2008). The Cost of Lower Self-Esteem: Testing a Selfand Social-Bonds Model of Health. Journal of Personality and Social Psychology, 94(3), 412-428. https://doi.org/10.1037/0022-3514.94.3.412

[25] Park, L. E., \& Maner, J. K. (2009). Does SelfThreat Promote Social Connection? The Role of SelfEsteem and Contingencies of Self-Worth. Journal of Personality and Social Psychology, 96(1), 203-217. https://doi.org/10.1037/a0013933 